https://nv.nltu.edu.ua

https://doi.org/10.15421/40280904

$@$ Correspondence author

Article received $16.10 .2018 \mathrm{p}$.

Article accepted 25.10.2018 p.

H. I. Bashnianyn

удк 331.5.024.5

H. I. Bashnianyn', T. I. Horodyskyy', Ya. S. Lapchuk ${ }^{2}$

${ }^{1}$ Lviv University of Trade and Economics, Lviv, Ukraine

${ }^{2}$ Drohobych Ivan Franko State Pedagogical University, Drohobych, Ukraine

\title{
ADAPTATION OF EUROPEAN EMPLOYMENT POLICY TO THE UKRAINIAN ECONOMY REALITIES
}

\begin{abstract}
The article deals with the current state of unemployment in Ukraine. Comparison of the unemployment rates with the European countries is conducted. The employment policy in the European Union (EU) was analyzed. The analysis and generalization of features of labour market in countries of the EU are conducted. The scientific results and tasks for further research were outlined. The actual problems of the current development of the labour market in Ukraine and countries of the EU are revealed. The main purpose of the paper is to explore the theoretical aspects of the formation of employment system and to consider the European experience of employment systems regulation in selected countries. The study revealed that in today's conditions of development of the national economy the labour market occupies an important place. One of the most important tasks of any state is defined to be the regulation of the labour market. At the present stage, the problems of the labour market become the most urgent in countries of the EU. This is due to a change in the structure of the pan-European labour market, as well as to the globalization of the world economy. The study found that overcoming unemployment and increasing employment are the main tasks of the EU. The main drivers, motivations and consequences of undeclared work in the EU are identified. The impact of the European employment strategy was studied. Regulation of EU main programs and initiatives that concern the lowering of unemployment, the main aim of which is improving of the education and employability of people was examined. Based on the analysis of the relevant European experience, challenges have been identified that should be taken into account when developing the state employment policy of Ukraine in the medium and long run periods. The recommendations regarding the borrowing of Ukraine's positive experience of the EU towards the employment policy are provided. Analysis of the labour market in the EU and Ukraine showed that the European integration of Ukraine opens the possibility for sustainable economic development. Borrowing of foreign experience will allow Ukraine to create conditions for more efficient functioning of the system of employment. The practical value of the research presented in the article is in identification of promising directions for increasing the efficiency of employment policy in Ukraine on the basis of the experience of member countries of the EU.

Keywords: unemployment; labour market; entrepreneurial activity; competitive labour force; European employment strategy; unemployment rate.
\end{abstract}

Introduction. The creation of a common labour market, freedom of movement for workers in the EU, a common strategy for employment can be considered as one of the most important achievements of the EU. Although the global economic crisis, demographic aging trends and global competition significantly affected the labour market by worsening employment conditions, still the EU continues to pursue a targeted policy for balancing the labour market, using pan-European and national capabilities.

Countries where youth unemployment is still very high despite the end of the world financial and economic crisis are the peripheral ones in the East and South. In some European countries, the youth unemployment rate is over 40 percent and the ratio to the adult unemployment rate is above 3 , meaning that young people have more than 3 times the chances of adults to experience unemployment. The main reason why this is the case is that high youth unemployment countries experience sluggish economic growth.
Education systems need important reforms and investment, which should not be blocked by the constraints set by the Maastricht Treaty and the Fiscal Compact (Aina et al., 2013; Bongardt et al., 2013; Maisto et al., 2017; Pastore, 2017).

The most recent evidence shows very great differences in the social situation across European countries and between different groups. Some countries have been more affected by the economic crisis than others, and some countries have been able to benefit more from recent economic improvements than others (Antonopoulis et al., 2014; Cournede et al., 2015; Dabla-Norris et al., 2015; Healy, 2017; Leahy et al., 2013; Mazower, 2015; Werner et al., 2016).

In the last 5 years, economic governance and its reform have predominated, often at the expense of the development of the social dimension. And the Lisbon Treaty creates some space for a reappraisal of old norms: in particular with its reference to a 'social market economy'. The EU has

\section{Інформація про авторів:}

Башнянин Григорій Іванович, д-р екон. наук, професор, завідувач кафедри теоретичної і прикладної економіки. Email: natdumich@meta.ua

Городиський Тарас Іванович, канд. екон. наук, доцент, кафедра економіки та менеджменту. Email: natdumich@meta.ua Лапчук Ярослав Степанович, канд. екон. наук, доцент, кафедра економіки та менеджменту. Email: natdumich@meta.ua Цитування за ДСТУ: Bashnianyn Н. І., HorodyskyуT. I., Lapchuk Ya. S. Adaptation of European employment policy to the Ukrainian economy realities. Науковий вісник НЛтУ України. Серія Економічна. 2018, т. 28, № 9. С. 27-30

Citation APA: Bashnianyn, H. I., Horodyskyy, T. I., \& Lapchuk, Ya. S. (2018). Adaptation of european employment policy to the Ukrainian economy realities. Scientific Bulletin of UNFU, 28(9), 27-30. https://doi.org/10.15421/40280904 
shown the ability to tack with the wind in social matters and to deliver a floor of rights. This has proved to be valuable and sustainable. The EU's regenerative capacity in the field of social policy needs to be shown again (Barnard, 2014; Pochet et al., 2013; Witte, 2013).

After the crisis, the gender gap in employment in the EU shows some convergence, though there is an important variation among regions and by education levels.

In the last decades, the participation of men and women on the labour market showed different trends as men's participation has decreased while women's participation has increased. Therefore, the employment gender gap has narrowed considerably, though it is far from being closed (Jaba et al., 2015).

However, at the present time, there is a need to increase attention on the problems of Ukraine's entry into the European economic space, including the labour market, when studying the methodological and practical aspects of management of social and labour potential. The urgency of the topic is determined by the prospect of Ukraine's joining the pan-European system of social and labour relations.

Despite the existence of a large number of thorough researches on current trends in the labour market and unemployment problems, the factors affecting the unemployment rate in the country remain insufficiently studied. The article aims at outlining the areas of improving social and labour relations and increasing the labour competitiveness in Ukraine, taking into account the experience of applying active employment policy in the countries of the EU.

Materials and methods. A wide range of commonly used methods of scientific research has been applied, namely: a retrospective analysis, which determines the nature and causes of unemployment; methods of statistical analysis used to study the impact of various macroeconomic indicators on employment; methods of comparative analysis - to compare the views of scientists - economists on the employment policy and the study of employment processes in different economies; methods of systems analysis.

The experience of past decades has shown that unemployment is characterized by a permanent nature. Unemployment has become a major factor in the destabilization of the socio-economic situation in many countries of the world. It has become stable and chronic, and struck the wide groups of population.

Results. In the market economy, long-term unemployment is inevitable, which has a lot of difficult problems. The responsibility of any country is to regulate the labour market in order to support employment, reduce forced unemployment, and provide material support for the unemployed.

Unemployment causes negative economic, social and psychological consequences. It potentially reduces the production of GDP, leads to loss of income of the populations. The social derivative of reducing employment is the deepening of inequality in society.

The regulation of the common European labour market is not harsh: each country has its own employment programs, coordinates at the EU level, develops a pan-European employment strategy, and aids to individual countries that are not moving well enough to implement the strategy. At the common European level, there are also clearly defined minimum labour rights and guarantees for workers.
It should be noted that in recent years in developed countries the priority is the active policy of employment, aimed not at overcoming unemployment by providing any jobs registered as unemployed, but at improving the qualitative characteristics of the working population, which contributes to the growth of employment. Different types and patterns of employment policy have been developed and applied in each European country today, but their common feature is to recognize the priority of investment in the development of labour potential competitiveness, instead of the cost to help the unemployed. Therefore, an active employment policy is appropriate to treat as a system of institutional, legal and economic influencing instruments on the level of economic activity of the population, its motivation to work, as well as the mobility and competitiveness of employees.

It is worth noting that for EU member states there are significant differences in the employment rate of the population aged 20-64. Thus, the highest levels of employment are observed in those non-EU countries: $79.5 \%$ in Iceland, $77.1 \%$ in Norway, and $76.6 \%$ in Switzerland.

On the basis of differences in the employment rate of the population of the EU can be divided into three groups. It is expedient to include to the first of them countries with high (above $70 \%$ ) employment level - Sweden, Denmark, Germany, Finland, the Netherlands, Austria and Estonia. These countries are characterized by a high level of labour market infrastructure, the possibility of combining work with vocational training, which positively affects the level of employment.

The second group is formed by countries with an average employment rate of the population aged 20-64 (not lower than $60 \%$ ) - Great Britain, France, Lithuania, Latvia, Czech Republic, etc. These countries have a competitive economy, balanced development of various sectors of the national economy, and they have a high degree of integration into a Single Economic Space.

As for the third group of countries, the employment rate of which is lower than $60 \%$, it mainly includes new members of the EU - Poland, Slovakia, Hungary, Romania, as well as Southern Europe countries - Italy, Spain, Greece, Croatia, Malta. The low level of employment in these countries is determined by a large number of factors - the imperfect sectoral structure of the economy, lack of investment activity, and the shortcomings of the functioning of the financial system (Zvonar, 2015).

Consequently, we can conclude that for Ukraine, which has just begun its path to European integration, and for the newly integrated countries of the EU, there are common problems in the field of employment. In particular, most regions of Ukraine are characterized by high unemployment, whose actual rates, as a rule, differ significantly from the officially registered.

Discussion. By studying the experience of developed countries, we can state that the employment service is more successful where it is subordinated to state authorities and has the staff of highly skilled employment specialists.

Thus, in the Netherlands and Finland, in particular, the employment services are the working offices of the ministries of labour, which operate under their uninterrupted control. While in Sweden, France, Germany, Spain and Belgium, employment services are separate institutions that are independent. The Ministry of Labour through its responsible representative exercises control over them. And, 
finally, in Switzerland, the employment service is primarily controlled by local authorities in the presence of a federal (confederal) coordinating body.

Having examined the experience of the functioning of the public employment services of some European countries, we can conclude that in order to move from the socialist system of full employment to the market model of employment, it is necessary to completely abandon the use of direct policy methods for managing labour potential and, in the main, economic levers of labour regulation, which in fact are confirmed by developed countries.

Special attention should be paid, in particular, to the formulation of a clear and understandable national policy on the implementation of benchmarks set at the pan-European level.

Conclusion. From the analysis of the experience of European countries it follows that in order to mitigate the problems in the labour market, it is necessary to implement a certain set of transformations that will create a more efficient system of employment of the country:

- radical change of the passive methods of the employment policy influencing the active, that is, contributing to the creation of additional jobs, self-employment and retraining of the unemployed population;

- create a favourable investment climate, which will further increase the number of jobs;

- adopt a number of legislative acts regulating labour relations between the employee and the employer;

- conduct constant control over the conclusion and implementation of collective agreements at enterprises of all forms of ownership;

- create favourable conditions for the development of small business.

Considering the European experience, in shaping the Ukrainian model of the labour market and employment policies, it is imperative to draw attention to the fact that a socially oriented market economy supports high rates of economic growth and a reasonable level of social protection and social consensus.

The further research will be directed to in-depth study of the problem of employment and unemployment in the countries of the EU and countries bordering Ukraine, to investigate how the frustrated countries of the EU overcome the problems of low employment and unemployment, and also link entrepreneurship and unemployment.

\section{Перелік використаних джерел}

Aina, C., Baici, E., Casalone, G., \& Pastore, F. (2013). Il fuoricorsismo fra falsi miti e realtà. Economia \& Lavoro, 48, 147-154.

Antonopoulis, R., Adam, S., Kijong, K., Masterson, T., \& Papadimitriou, D. B. (2014). Responding to the Unemployment Challenge: A Job Guarantee Proposal for Greece. Observatory of Economic and Social Development, Labour Institute, Greek General Confederation of Labour.

Barnard, C. (2014). EU Employment Law and the European Social Model: The Past, the Present and the Future. Advance Access published Current Legal Problems, 67, 199-237.

Bongardt, A., \& Torres, F. (2013). Forging Sustainable Growth: The Issue of Convergence of Preferences and Institutions in EMU. Intereconomics $48,72-77$.

Cournede, B., Denk, O., \& Hoeller, P. (2015). Finance and Inclusive Growth. Authorised for publication by Catherine L. Mann, OECD Chief Economist and G20 Finance Deputy. OECD Publishing.

Dabla-Norris, E., Kochhar, K., Suphaphiphat, N., Ricka, F., \& Tsounta, E. (2015). Causes and Consequences of Income Inequality: A Global Perspective. International Monetary Fund.

Healy, S. (2017). Strategies to combat poverty and generate decent employment in the European Union. New York: Presentation at UN Expert Group.

Jaba, E., Pârtachi, I., Chistruga, B., \& Balan, C. B. (2015). Gender employment gap in EU before and after the crisis. Procedia Economics and Finance, 20, 326-333. https://doi.org/10.1016/S2212-5671(15)00080-5

Leahy, A., Healy, S., \& Murphy, M. (2013). The European Crisis and its Human Cost. Brussels: Caritas Europa, 360 p.

Maisto, M., \& Pastore, F. (2017). Alternanza scuola-lavoro: Un bilancio ad un anno dall'attuazione. Economia \& Lavoro 51, 133-145.

Mazower, M. (2015). Why the Eurozone crisis is just part of our long struggle for peace. The Guardian, $320 \mathrm{p}$.

Pastore, F. (2017). Getting It Right: Youth Employment Policy within the EU. CESifo Forum, 18, 26-33.

Pochet, P., \& Degryse, C. (2013). Monetary Union and the Stakes for Democracy and Social Policy. 19 Transfer, 103, 107-108.

Werner, A., \& Lim, M. (2016). Putting the Living Wage to Work: Strategies and Practices in Small and Medium Sized Enterprises (SMEs). London: Barrow Cadbury Trust; Middlesex University London and University of Liverpool, $316 \mathrm{p}$.

Witte, F. (2013). EU Law, Politics and the Social Question. 14 ELJ, $581,589-90$.

Zvonar, Y. P. (2015). Aktyvna polityka zaynyatosti v krayinakh Yevropeys'koho Soyuzu ta mozhlyvosti yiyi zastosuvannya v Ukrayini. Naukovyy visnyk Mukachivs'koho derzhavnoho universytetu, 2(4), 145-150. [In Ukrainian].

Г. І. Башнянин ${ }^{1}$, Т. І. Городиський², Я. С. Лапчук ${ }^{2}$

${ }^{1}$ Львівський торговельно-економічний університет, м. Львів, Україна ${ }^{2}$ Дрогобииький державний педагогічний університет ім. Івана Франка, м. Дрогобич, Украӥна

\section{АДАПТАЦІЯ ЄВРОПЕЙСЬКОЇ ПОЛІТИКИ ЗАЙНЯТОСТІ ДО РЕАЛІЙ УКРАЇНСЬКОЇ ЕКОНОМІКИ}

Розглянуто сучасний стан рівня безробіття в Україні, зроблено порівняння рівнів безробіття з країнами Європи. Досліджено політику зайнятості у країнах Європейського Союзу (СС), проаналізовано та проведено узагальнення особливостей ринку праці в країнах ЄС. Проаналізовано наукові результати та окреслено наукові завдання проведення подальших досліджень. Виявлено та розглянуто актуальні проблеми сучасного розвитку ринку праці України та країн ЄС. Досліджено теоретичні особливості формування системи зайнятості населення та розглянуто європейський досвід регулювання систем зайнятості на прикладі окремих країн. Виявлено, що у сучасних умовах розвитку національної економіки ринок праці посідає важливе місце. Встановлено, що одним з найважливіших завдань будь-якої держави є регулювання ринку праці. На сучасному етапі у країнах ЄС найбільш актуальними стають проблеми ринку праці. Це пов'язано зі зміною структури загальноєвропейського ринку праці, а також із глобалізацією економіки світу. З'ясовано, що подолання безробіття та підвищення рівня зайнятості є основними завданнями ЄС. Охарактеризовано ключові напрями та підходи політики ЄС у сфері зайнятості. Визначено основні рушійні сили, мотивації та наслідки зайнятості в ЄС. Оцінено вплив європейської стратегії зайнятості. Охарактеризовано закономірності основних європейських програм та ініціатив, спрямованих на зниження безробіття, основною метою яких є покращення освіти та трудової мобільності людей. На основі аналізу відповідного європейського досвіду визначено виклики, що повинні враховуватися під час розроблення державної політики зайнятості України на середньо- та довготермінову перспективу. Надано рекомендації щодо запозичення Україною позитивного досвіду ЄС сфері зайнятості. Аналіз особливостей ринків праці ЄС і України показав, що європейська інтеграція для України відкриває мож- 
ливість сталого економічного розвитку. Запозичення зарубіжного досвіду дасть змогу Україні створити умови для більш ефективного функціонування системи зайнятості населення. Практичне значення здійснених у роботі досліджень полягає у тому, щоб, спираючись на досвід країн-учасниць ЄС, визначити перспективні напрямки підвищення ефективності політики зайнятості в Україні.

Ключові слова: безробіття; ринок праці; підприємницька діяльність; конкурентна робоча сила; Європейська стратегія зайнятості; рівень безробіття.

Г. И. Башнянин 1 , Т. И. Городыский², Я. С. Лапчук²

${ }^{1}$ Львовский торгово-экономический университет, г. Львов, Украина ${ }^{2}$ Дрогобычский государственный педагогический университет им. Ивана Франко, г. Дрогобыч, Украина

\section{АДАПТАЦИЯ ЕВРОПЕЙСКОЙ ПОЛИТИКИ ЗАНЯТОСТИ К РЕАЛИЯМ УКРАИНСКОЙ ЭКОНОМИКИ}

Рассмотрено современное состояние уровня безработицы в Украине, сделано сравнение уровней безработицы со странами Европы. Исследовано политику занятости в странах Европейского Союза (ЕС), сделан анализ и проведено обобщение особенностей рынка труда в странах ЕС. Проанализированы научные результаты и намечены научные задачи дальнейших исследований. Выявлены и рассмотрены актуальные проблемы современного развития рынка труда Украины и стран ЕС. Исследованы теоретические особенности формирования системы занятости населения и рассмотрен европейский опыт регулирования систем занятости на примере отдельных стран. Выявлено, что в современных условиях развития национальной экономики рынок труда занимает важное место. Установлено, что одной из важнейших задач любого государства является регулирование рынка труда. На современном этапе в странах ЕС наиболее актуальными становятся проблемы рынка труда. Это связано с изменением структуры общеевропейского рынка труда, а также с глобализацией экономики мира. Выяснено, что преодоление безработицы и повышения уровня занятости являются основными задачами ЕС. Охарактеризованы ключевые направления и подходы политики ЕС в сфере занятости. Определены основные движущие силы, мотивации и последствия занятости в ЕС. Оценено влияние европейской стратегии занятости. Охарактеризованы закономерности основных европейских программ и инициатив, направленных на снижение безработицы, основной целью которых является улучшение образования и трудовой мобильности людей. На основе анализа соответствующего европейского опыта определены вызовы, которые должны учитываться при разработке государственной политики занятости Украины на средне- и долгосрочную перспективу. Даны рекомендации по заимствованию Украины положительного опыта ЕС в сфере занятости. Анализ особенностей рынков труда ЕС и Украиной показал, что европейская интеграция для Украины открывает возможность устойчивого экономического развития. Заимствование зарубежного опыта позволит Украине создать условия для более эффективного функционирования системы занятости населения. Практическое значение осуществленных в работе исследований заключается в том, чтобы, опираясь на опыт стран-участниц ЕС, определить перспективные направления повышения эффективности политики занятости в Украине.

Ключевые слова: безработица; рынок труда; предпринимательская деятельность; конкурентная рабочая сила; Европейская стратегия занятости; уровень безработицы. 